\title{
Design and Development of Solar Operated Automatic Seed Sowing Machine
}

\author{
Rupesh Kongare $^{1}$, Sagar Wankhede ${ }^{2}$, Sushil Sharma ${ }^{3}$, Remu Dhore ${ }^{4}$, Talash Bhoyar ${ }^{5}$, Saurabh \\ Bawane $^{6}$, Pranit Thombre ${ }^{7}$, Prof. A. N. Madne ${ }^{8}$ \\ ${ }^{1-7}$ Students Department of Mechanical Engineering, \\ KDK College of Engineering, Nagpur, India \\ ${ }^{8}$ Assistant Professor, Department of Mechanical Engineering, \\ KDK College of Engineering, Nagpur, India
}

\begin{abstract}
Agriculture Sector is the backbone of Indian Economy. There is a need for Improvement in agriculture sector, which can be achieved by using advanced Technological methods for farming processes like digging, sowing and irrigation Etc. Mechanization reduces labors cost and improves the overall productivity without affecting the quality of soil. This project represents a machine which can carry out various farming activities simultaneously. Air and Noise Pollution are caused by the combustion of fossil fuels in IC Engines and External Combustion Engines. To negate these problems, this machine uses Solar Energy as an eco-Friendly energy resource. Solar Panel is used to convert solar energy into Electrical energy and a DC Motor converts this electrical energy into mechanical Energy for digging operation. Seed Hopper are Used for seed sowing and irrigation operations respectively. This machine Maintains seed to seed spacing and row to row spacing. It also decreases the Cost of sowing the seeds and requirement of labors.
\end{abstract}

\section{I- INTRODUCTION}

$\mathrm{T}$ oday the environmental impact of agricultural production is very much in Focus and the demands to the industry is increasing. In the present scenario most Of the countries do not have sufficient skilled man power in agricultural sector And that affects the growth of developing countries. Therefore farmers have to Use upgraded technology for cultivation activity (digging, seed sowing, Fertilizing, spraying etc.). So it's a time to automate the sector to overcome this Problem. In India there are $70 \%$ people dependent on agriculture. So we need to Study on improving agricultural equipment. Innovative idea of our project is to Automate the process of digging and seed sowing crops such as sunflower, baby Corn, groundnut and vegetables like beans, lady's finger, pumpkin and pulses like Black gram, green gram etc. and to reduce the human effort. Since we have lack Of man power in our country, it is very difficult to do digging and sowing Operation on time, Automation saves a lot of manual work and speed up the Cultivation activity. The energy required for this robotic machine is less as Compared with other machines like tractors or any agriculture instrument, also This energy is generated from the solar energy which is found abundantly in Nature. Pollution is also a big problem which is eliminated by using solar plate.

\section{II- METHOLOGY}

In this machine a solar panel is used to consume solar energy and this Energy is converted into electrical energy. The electrical energy is stored Inside a $12 \mathrm{v}$ 


\section{International Journal of Innovations in Engineering and Science, www.ijies.net}

battery, which then gives the necessary power to a DC motor. This power is then transmitted to the relay circuit and the seed sowing Mechanism and the digging mechanism. The seed is taken inside through a Big size funnel and then it sowed to the ground through a pipe in connected to gear motor of $60 \mathrm{Rpm}$ to make a continuous seed taking from a funnel. Relay Circuit is used to switch on/off the circuit when needed and better Performance of the machine.

\section{III- DESIGN}

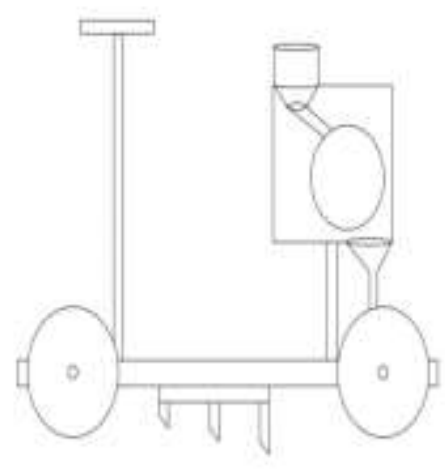

\section{IV- CONCLUSION}

In India about $70 \%$ of the population lives in rural areas and their main source of income is dependent on agriculture sector. So, it is important to have special focus on agriculture sector and to apply latest technologies and methods which are more advance and efficient. This will lead to better growth rate of the country. Our machine which operates on solar power when compared to different traditional seed sowing methods, it can be concluded that:

- Sowing rate can be controlled

- Seed spacing can be achieved

- Less manual power is required

- No pollution is caused

- Economical

- Variety of seeds can be sowed

\section{REFERENCES}

[1] Sahay (1990), Principals of Agricultural Engineering (2005), Volume 1, Text book published by Jain brothers, New Delhi, India.

[2] R. Joshua, V. Vasu and P. Vincent "Solar Sprayer - An Agriculture Implement”, "International Journal of Sustainable Agriculture” 2 (1): 16-19, 2010 ISSN 20792107.

[3] N.Iqbal, N.Akbar, M.Ali, M.Sattar, L.Ali."Effect of seed rate and Row spacing on yield and yield components of Wheat "Journal of Agricultural Research,48(2).

[4] P.P. Shelke, "frontline demonstration on bullock-drawn planter enhances yield of soya bean crop. International journal of farm science 1(2):123-128, 2011.

[5] Ramesh, M.V., Amarnath, J., Kamakshaiah, S. and Rao, G.S. Speed Control of Brushless DC Motor by using Fuzzy logic P I Controller. ARPN. 2011. 6(9). 